\title{
RARE PLANTS FOUND NEAR HUDSON BAY, SASKATCHEWAN
}

DONALD F. HOOPER, Box 40, Somme, Saskatchewan. SOE 1 NO

Greenbush Campsite is in the Northern Provincial Forest Reserve, twelve miles west of Hudson Bay, on the south side of Highway No. 3. Here on a Jackpine ridge are good camping facilities, with a camp kitchen, a well with good water, outhouses, swings and teeter-totter and a good number of picnic tables (but no electrical power).

On the west side of the campsite is a steep slope down to the Greenbush River. Along the river flat grow rich stands of Black Spruce and clumps of Speckled Alder. The river is a very cold stream that comes out of the Pasquia Hills and flows into the Red Deer River two and one-half miles south of the highway.

Southeast of the campsite, the ridge drops off into a large swampy area, which covers about two sections of land. The outer edges of the swamp are encircled by stretches of open, spongy, fenland. In these fens grow several varieties of sedges, with bog willows, and birch shrubs. Pitcher plants (Sarracenia purpurea) are in abundance everywhere. There must be more than one hundred acres of them! In the center of the swamp is a high sphagnum bog, which surrounds Shenigan Lake. Scattered through the bog are short trees of Black Spruce and Tamarack.

I received a letter from Dr. V.L. Harms (Curator of The W.P. Fraser Herbarium at the University of Saskatchewan, Saskatoon), saying that he was coming up our way again in July to collect plants. Les Baker and I decided to do some scouting around to try and find some interesting spots to take Vern to when he came. My brother Ron came in June to collect insects for the Provin- cial Museum, in Regina, so we went with him for a few days.

We arrived at Greenbush Campsite on the evening of 23 June 1981. We didn't get to sleep very early, as we stayed up with Ron, who was busy collecting moths until after midnight. About five o'clock the next morning Les and I went for a hike through the woods, the vegetation being very wet with dew. One might wonder if anything noteworthy could be found near this campsite, with a paved highway and a continuous flow of traffic. But the 24th proved to be an exceptional day, with some interesting discoveries.

Entering the open fen on the edge of the muskeg, we soon found a rare plant species. A number of Purple Louseworts (Pedicularis macrodonta) were growing along the tracks of an old winter road crossing the swamp. This species is rare in all three of the prairie provinces. $^{7}$ This encouraged us to look further. On the mossy hummocks where the fen and bog met, we found Roundleaved Sundews (Drosera rotundifolia). Further on were Swamp Pinks (Arethusa bulbosa), often called Dragon's Mouth Orchids. They were scattered along through the stunted tamarack in the cold bog. We counted twenty-six in all! This was spectacular, for Vern told us later that this species is so rare that prior to this no more than two to five specimens have been found in any one locality in Saskatchewan. It is then very clear that these beautiful orchids should never be picked or dug up (except very sparingly for scientific collections). Swamp Pinks range from northwestern and central Saskatchewan, east to Labrador, and south into the northern 


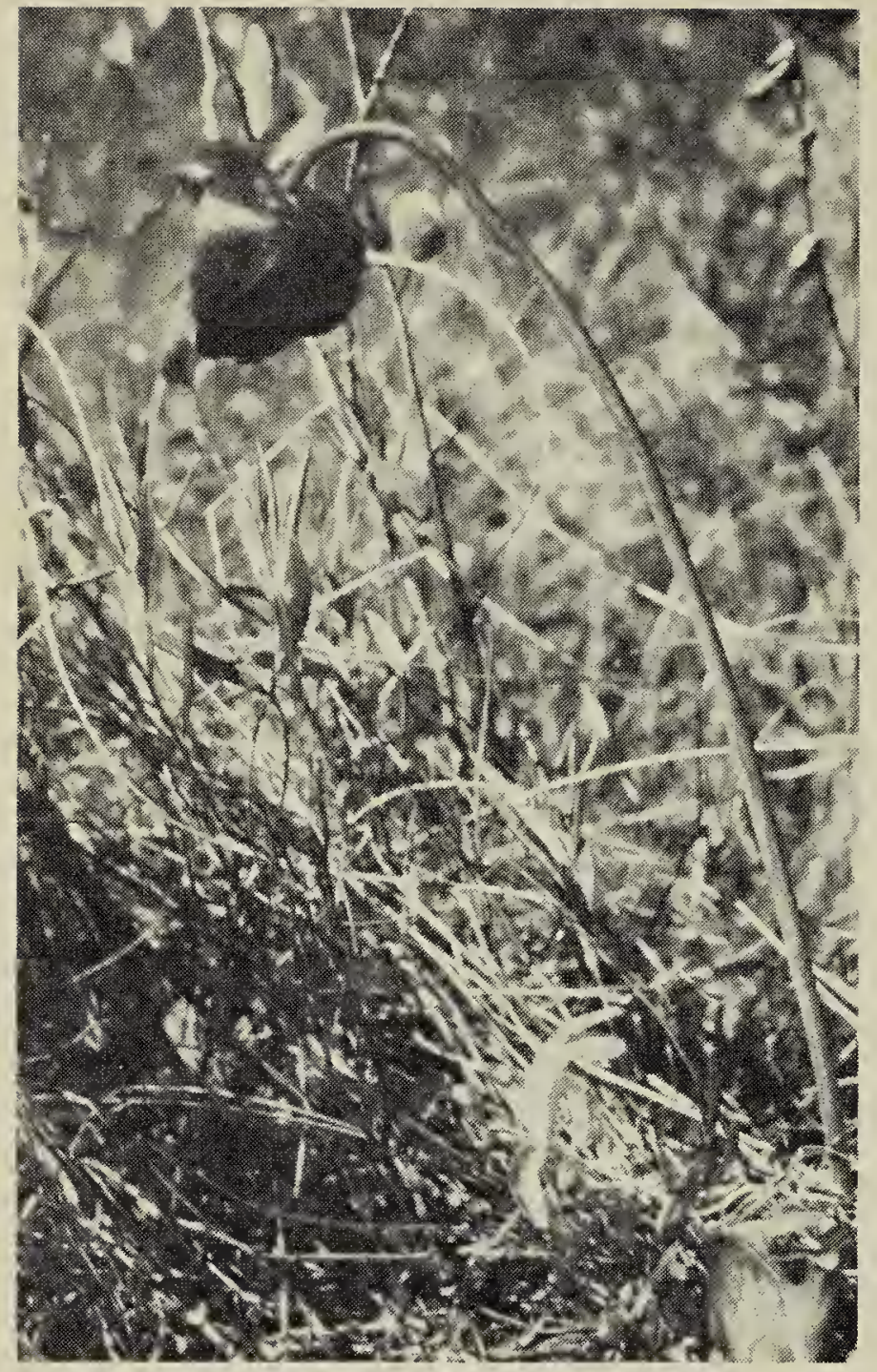

Swamp Pink and Pitcher Plant

Ron Hooper

states. They are rare in Manitoba, and in no less than ten of the states from Minnesota eastward. ${ }^{7}$ We returned back to camp with great excitement. After all it isn't every day that two very rare species of plants can be found before breakfast!

After breakfast, Les and I returned to the swamp and crossed over to the high bog near Shenigan Lake. Labrador Tea, Pale Laurel, Bog Rosemary and Leatherleaf were common shrubs. A few Bonaparte's Gulls were flying around, and one was sitting on its nest in the top of a Black Spruce near the shore. It looked down at us quite unconcerned as we walked by.

At the north end of the lake was a wet run with floating bog. Here, Sweet Gale was a common shrub. As we were examining and smelling its fragrant leaves, a Lesser Yellowlegs scolded and complained loudly. I am sure that there was a nest nearby. Further north was a wet fen with marshy spots. This area was very calcareous, the water puddles being bordered with a white scum. Around these puddles grew many Slenderleaved Sundews (Drosera linearis). As we circled the area we found that there must have been at least three acres of them! This species is rare anywhere in Canada, with only a few previous records for Saskatchewan. ${ }^{7}$ (In July, I found more Slender-leaved Sundews in a swamp north-east of Porcupine Plain.) To the west side of the calcareous area, a good number of Oblong-leaved Sundews (Drosera anglica) were also found.

While at the campground, we saw a female Evening Grosbeak. As far as I know there is no nesting record yet for this species in Saskatchewan. Godfrey's breeding range for Canada is based largely on summer occurrences, as definite breeding data are relatively few. For Saskatchewan he refers to the summer sight records from the Nipawin and Somme birds lists. ${ }^{25}{ }^{4} \mathrm{I}$ am sure that they nest in the area, because on 23 June 1981, when I was in the vicinity of the Pasquia River north of Hudson Bay, I saw a pair of Evening Grosbeaks scolding around some scattered spruce trees (they often nest in a conifer). I was unable, however, to locate the nest.

In the afternoon of 24 June 1981 we went up into the Pasquia Hills on the Fir River Road. This road leaves Highway 3 five miles west of Hudson Bay. At Mile 15 , we walked west down the township cutline to an open boggy fen. In the shaded mossy woods on the way to the fen we found a few Fringed Milkworts (Polygala paucifolia), which are dainty flowers with pink-purple wings. This forest species is infrequent at most known localities across Saskatchewan. $^{7}$

At the fen we found some more Purple Louseworts. We discovered later that these plants are quite abundant in the immediate area. We also found a 


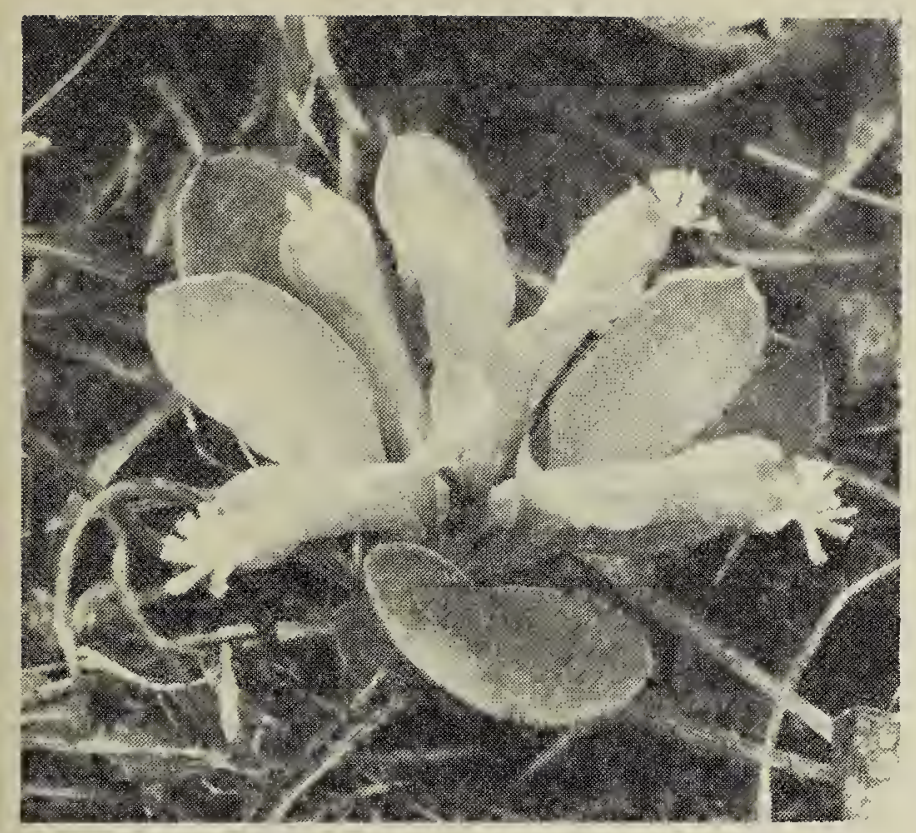

Fringed Milkwort

Wayne C. Harris

few specimens of Meadow Bitter Cress (Cardamine pratensis), another rare species. ${ }^{6}$

On 6 July 1981, Dr. Vern Harms, the herbarium assistant, Patricia Sky, Les Baker and I returned to Greenbush Campsite. Here a great variety of species were collected for the Fraser Herbarium. The next day on 7 July 1981 we went to the fen on the Fir River Road. We were only able to collect here for two hours, because of rain, but in the short time that we were there, two important discoveries were made. In the middle of the fen a specimen of Marsh (or Swamp) Saxifrage (Saxifraga pensylvanica) was found. This is a new plant record for Saskatchewan. We did not expect to find this species, as it is rare in southeastern Manitoba. ${ }^{6}$

On the south side of the fen the water filtered through a tamarack swamp. Rich growths of horsetail were the main understory plants. In this cool, moist, shaded situation there were twelve plants of the Large Yellow Lady's Slipper (Cypripedium calceolus var. pubescens). Two specimens were collected. These were the first samples of the variety pubescens for the Fraser Herbarium. Compared to the Small Yellow Lady's Slipper (var. parviflorum Fern.), our regular type, these flowers were gigantic in size. Bernard de Vries (pers. corr. with V. L. Harms, 25 February 1982) reports other verified Saskatchewan records of the Large Yellow Lady's Slipper, filed in the Fort Qu'Appelle Herbarium, from along the Kelsey Trail near Rice River and the Otosquen Road, both localities also in the Pasquia Hills.

In November Les and I went back to the fen on the Fir River Road, to try and locate some more Marsh Saxifrage plants (they grow up to $80 \mathrm{~cm}$ in height). It was much easier getting around on the ice and frozen bog, than it was in the summer time. We searched over a lot of the area, but found none. However we did find a few Dock plants sticking out of the ice. I sent samples to Vern, and he identified them as Great Water Dock (Rumex orbiculatus). This relatively uncommon species grows in swamps and shallow water of the Boreal Forest. ${ }^{6}$ It has been found in Saskatchewan, as far northwest as Cluff Lake. ${ }^{3}$

I think that our few findings indicate that there are many kinds of plants yet to be found in the Porcupine and Pasquia Hills areas.

\section{Acknowledgement}

Appreciation is expressed to Dr. Vern

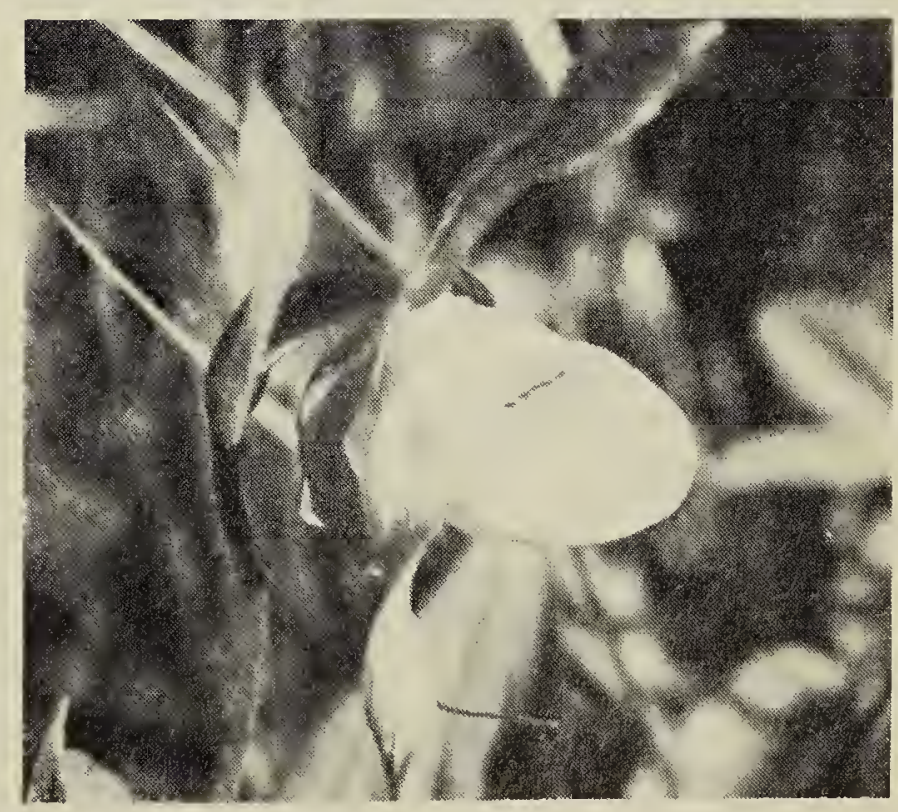

Large Yellow Lady's Slipper

Wayne C. Harris 
Harms for checking over this article and giving helpful suggestions.

${ }^{1}$ CORMACK, R. G. H. 1977. Wild Flowers of Alberta. Hurtig Pub. Co., Edmonton.

2 GODFREY, W. Earl. 1966. The Birds of Canada. Nat. Mus. Canada Bulletin 203, Ottawa.

${ }^{3}$ HARMS, Vernon L. 1978. A botanical inventory of the Cluff Lake Area, Northwestern Saskatchewan. Musk-ox 22.

${ }^{4}$ HOOPER, Ronald, and Donald. 1954. A preliminary list of the birds of the Somme District, Saskatchewan. Con. no. 3, Yorkton Nat. His. Soc.

\section{FUNGI PRESERVING}

WALTER KRIVDA, P.O. Box 864, The Pas, Manitoba. R9A $1 \mathrm{~K} 8$

Many of us in wandering in the woods in spring, summer or autumn find interesting fungi and wonder what are their names. For identification, specimens have to be collected and preserved. The process is surprisingly simple if the following steps are taken:

1. Collect a few of the best looking specimens. Avoid spoiled ones.

2. Lay them gills down in a basket, paper bag or box. (Do not use plastic bags!)

3. Carefully remove all the soil you can from the stem.

4. At home lay them on newspaper in an airy place.

5. Move them around a bit on the newspapers each day to prevent sticking.

6. Various larvae will emerge and die on the papers - shake them off.

There is hardly anything known about these insects in Canada. They develop into various delicate winged flies, some are Mycetophilids, Others ???
${ }^{5}$ HOUSTON, C. Stuart and MAURICE G. STREET. 1959. The Birds of the Saskatchewan River, Carlton to Cumberland. Sask. Nat. His. Soc. spec. pub. no. 2.

${ }^{6}$ LOOMAN, J. and BEST, K. F. 1979. Budd's Flora of the Canadian Provinces. Res. Bra. Ag. Can. pub. no. 1662.

MAHER, R. V., G.W. ARGUS, V.L. HARMS and J. H. HUDSON. 1979. The Rare Vascular Plants of Saskatchewan. Nat. Mus. Can. Syllogeus no. 20, Ottawa.

${ }^{8}$ MOSS, F. H. 1959. Flora of Alberta, University of Toronto Press, Toronto.

${ }^{9}$ SCOGGAN, H. J. 1957. Flora of Manitoba. Nat. Mus. Can. Bulletin no. 140.

7. In about a week the fungi will dry completely and now will last indefinitely.

8. Each kind should be placed into an envelope or you can make packets by folding writing paper. The following information should be written on each: Location - Be specific to one-half mile; date of collection; the collector.

9. Number each collection.

10. Keep a note book - jot down other information on your specimens with the collection number. Changes occur in the drying process. Record the color of any spores that may have been released by the specimen as it dried.

11. Store your specimens, standing up, in shoe boxes in a dry place. They take little space and store well anywhere books can be kept.

12. Photographing prior to drying the same specimen would enhance the value of the specimens considerably.

I would be willing to name any fungi specimens sent to me. I have used this method since 1950 and have good specimens that require a minimum of attention. 